\title{
Riparian vegetation as a marker for bankfull and management discharge evaluation: The case study of Rio Torbido river basin (central Italy)
}

\author{
Ciro Apollonio, ${ }^{1}$ Andrea Petroselli, ${ }^{2}$ Paolo Cornelini, ${ }^{3}$ Vito Manzari, ${ }^{4}$ Federico Preti, 3,5 \\ Salvatore Grimaldi6
}

${ }^{1}$ Department of Agriculture and Forest Sciences (DAFNE), Tuscia University, Viterbo, Italy; ${ }^{2}$ Department of Economy, Engineering, Society and Business (DEIM), Tuscia University, Viterbo, Italy; ${ }^{3}$ Italian Association for Soil and Water Bioengineering (AIPIN), Florence, Italy; ${ }^{4}$ Department of Landscape and Biodiversity, City of Annecy, France; ${ }^{5}$ Department of Agricultural, Food, Environmental and Forestry Sciences and Technologies, University of Florence, Florence, Italy; ${ }^{6}$ Department for Innovation in Biological, Agro-food and Forest systems (DIBAF), Tuscia University, Viterbo, Italy

\begin{abstract}
Bankfull discharge estimation is a crucial step in river basin management. Such evaluation can be carried out using hydrological and hydraulic modelling to estimate flow-depths, flow velocities and flood prone areas related to a specific return period. However, different methodological approaches are described in the scientific literature. Such approaches are typically based either on the assumption that the bankfull discharge corresponds to a narrow range of return periods, or on the correlation to the river geomorphological or local descriptors, such as vegetation. In this study, we used high-resolution topographic data and a combined hydrological-hydraulic modelling approach in order to estimate bankfull discharge in the ungauged basin of Rio Torbido River (Central Italy). The field survey of plant species made it possible to investigate the link between the riparian areas and the bankfull discharge. Our results were in line with previous studies and showed a promising agreement between the results of the hydraulic modelling and the plant species present in the investigated river cross sections. The plant species position could be indeed used for a preliminary delineation of the riparian areas to be verified more deeply with the hydrological-hydraulic approach.
\end{abstract}

\footnotetext{
Correspondence: Andrea Petroselli, Department of Economy, Engineering, Society and Business (DEIM), Tuscia University, 01100 Viterbo, Italy.

E-mail: petro@unitus.it
}

Key words: Bankfull discharge; bank vegetation; floristic indicators; hydraulic modelling; hydrological modelling; riparian vegetation; unmanned aerial vehicle.

Received for publication: 17 December 2020.

Accepted for publication: 14 February 2021.

${ }^{\circ}$ Copyright: the Author(s), 2021

Licensee PAGEPress, Italy

Journal of Agricultural Engineering 2021; LII:1140

doi:10.4081/jae.2021.1140

This article is distributed under the terms of the Creative Commons Attribution Noncommercial License (by-nc 4.0) which permits any noncommercial use, distribution, and reproduction in any medium, provided the original author(s) and source are credited.

\section{Introduction}

In recent years, many studies have been introduced to estimate the formative, or bankfull, river discharge and the mutual link between the river hydrodynamic characteristics and riparian vegetation (Merrit et al., 2010; Bertoli et al., 2011; Gurnell et al., 2014).

Usually, the bankfull discharge is defined as the value related to the water depth of the river when it begins to flow out of its main channel and over its floodplain (Wolman and Leopold, 1957; Kilpatrick and Barnes, 1964; Riley, 1972; Pickup and Reiger, 1979; Williams, 1978; Harrelson et al., 1994; McCandless and Everett, 2002).

Woodyer (1968) analysed the possibility of determining a common bankfull frequency using data from gauging sites in New South Wales. He established that the frequencies with which the present floodplain level is exceeded for streams in New South Wales can be regarded as belonging to one frequency distribution with a reasonable degree of confidence. In particular, the approach proposed by Woodyer suggested to identify the active floodplain or its equivalent level, and distinguish floodplains from terraces. Specifically, floodplains resulting from the interaction of sedimentary and biological systems and hydrological regimes are strongly linked to the river bankfull discharge. However, it is technically challenging to relate these complex response systems to a specific flow value (Hughes, 1997).

Williams (1978) analysed four different methods to estimate the river bankfull discharge: i) a rating curve; ii) hydraulic geometry; iii) flow recurrence frequencies; and iv) a flow equation such as the Gauckler-Manning equation. He reached some interesting conclusions and, in particular, he underlined that the 1.5-years (or 1.58 -years) return period discharge would not be representative of bankfull discharge in a large number of investigated cases.

As a consequence, several definitions have been given to the representative channel-forming discharge, including bankfull, dominant, specified recurrence interval, and effective discharge. This worsened the confusion both in technical terminology and in the understanding of these important river processes (Copeland et al., 2000).

The three most applied deterministic definitions are briefly recalled hereafter. The first one is related to the bankfull discharge, which is normally defined as the maximum discharge that the channel can transport without overflowing in the floodplain. The second definition is related to the channel-forming discharge based on a specified return period (typically between 1.5 and 2.5 years). The third definition is related to the effective discharge, 
which is defined as the discharge that transports the largest fraction of the average annual bed-material load (Copeland et al., 2000). However, the field identification of bankfull indicators are reliable in stream reaches that are stable and alluvial (Knighton, 1984; Biedenharn et al., 2000).

An additional feature that is worth considering is the distribution of plant species near the river network, that can be linked to the hydrogeomorphological processes and landforms (Gurnell et al., 1995; Pett and Gurnell, 2005). However, the understanding of these connections is complex and challenging (Bendix and Hupp, 2000). For instance, the contribution of vegetation to hydraulic roughness is not at all negligible (e.g. Tabacchi et al., 2000; Forzieri et al., 2011; Errico et al., 2018). Indeed, dense riparian vegetation can have an unexpected influence on it, thus increasing the values of Manning coefficient of an order of magnitude (Arcement and Schneider, 1989). Moreover, Navratil et al. (2006) used a one-dimensional hydraulic backwater model to show in 16 river reaches that the transition between the main channel and the floodplain does not occur at a single discharge. Indeed, they identified a range of discharges and clarified the several bankfull definitions present in the literature.

However, for years, the technical community has frequently used the notion of bankfull discharge in terms of magnitude and frequency as a relevant concept in the analysis of river morphology, flood events and ecological systems (Navratil et al., 2006). Louckova (2011) asserted that vegetation patterns along river corridors are closely linked to natural dynamics and fluvial geomorphic processes. Consequently, the presence of a specific species can be symptomatic of precise hydrogeomorphic conditions. He also tried to identify the riparian species that have grown after flood events with a considerable return period, for example 500 years. Recently, other studies were conducted on flood disturbance due to vegetation using monitoring terrestrial photography
(Džubáková et al., 2015). Furthermore, it should be noted that the Italian legislation prescribes the safeguarding of native and riparian species that remain below the water level for $\mathrm{T}=30$ years (D.P.R. 14/04/1993), during riverbed maintenance interventions.

The literature typically suggests an arbitrary approach, which is too often disconnected from riparian vegetation. For this reason, in the present study, a combined hydrological-hydraulic modelling was applied to identify any relationship with the riparian species surveyed through field observations. In particular, in this work the mutual interaction between the bankfull discharge and the riparian vegetation was investigated in the Rio Torbido river basin (central Italy). The main aim of this manuscript is to investigate if the colonization of riverbank by woody riparian species has a correlation to the bankfull discharge.

\section{Materials and methods}

\section{Case study: the Rio Torbido river basin}

The study area is located within the Rio Torbido river basin (Lazio Region, central Italy - Figure 1). The Rio Torbido river basin is located in the municipality of Bagnoregio (centroid $42^{\circ} 37^{\prime} 48.00^{\prime \prime} \mathrm{N}, 12^{\circ} 05^{\prime} 21.48^{\prime \prime} \mathrm{E}$ ) in the northern part of the province of Viterbo, near Bolsena Lake. The river has a typical torrential regime, and is fed by the groundwater system of the Vulsine volcanic aquifer which is connected to the north-west with the Bolsena Lake.

The Rio Torbido River is a tributary to the Tiber River; its contributing area, at the confluence with the Tiber river, is equal to $61.7 \mathrm{~km}^{2}$, and the main channel length is approximately $20.3 \mathrm{~km}$. Maximum and average basin elevations are 625 and $373 \mathrm{~m}$ above

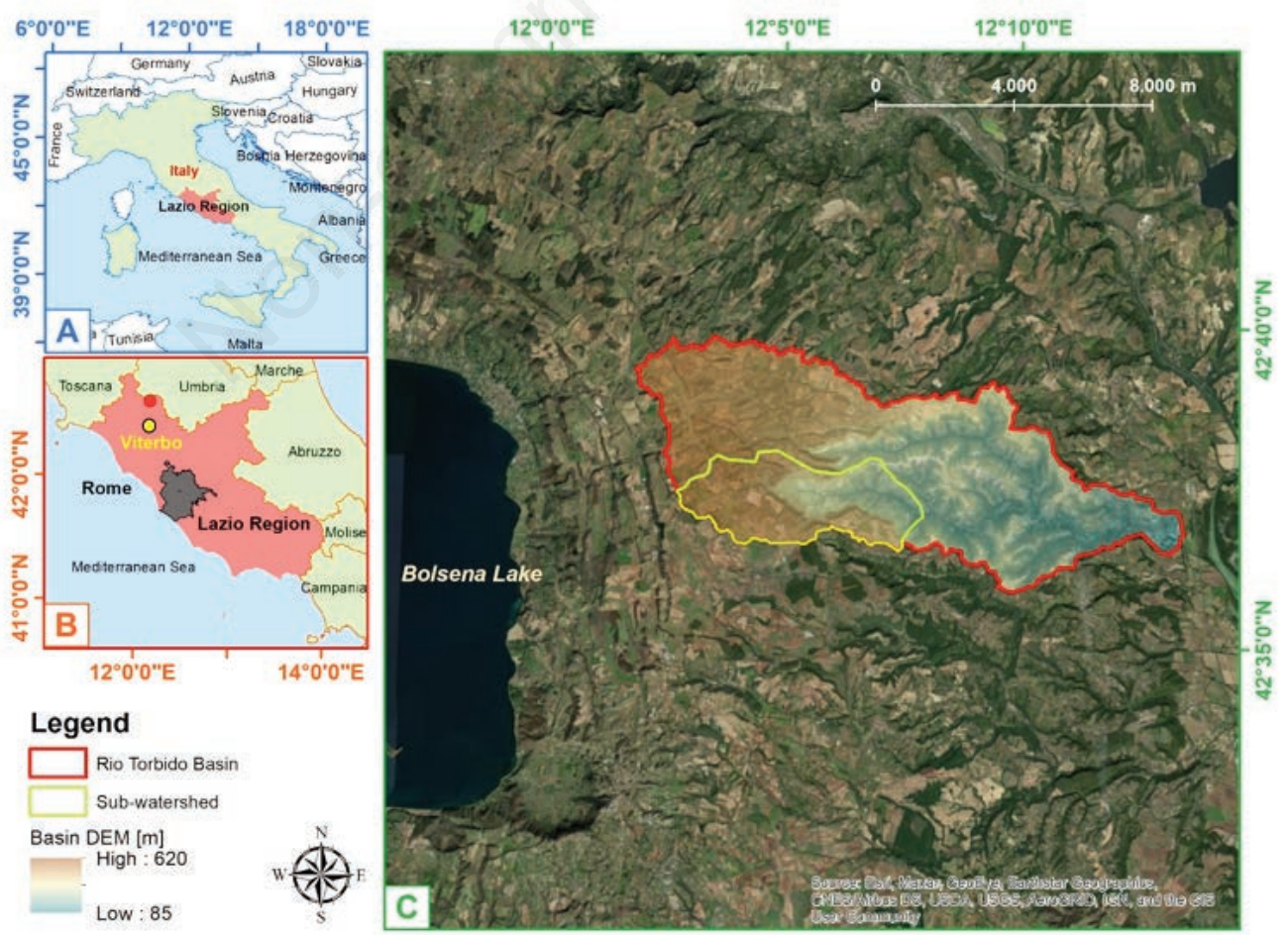

Figure 1. Description of the area under study. A) and B) geographical identification of the Rio Torbido river basin; C) digital elevation model (DEM) of river basin and sub-watershed under analysis. 
sea level, respectively. The sub-watershed analysed in this paper is characterized by an outlet with coordinates $42^{\circ} 36$ ' $55,54^{\prime \prime}$ N, $12^{\circ} 8^{\prime}$ 12.22 " E and has a contributing area equal to $13.5 \mathrm{~km}^{2}$.

In the Rio Torbido river basin three distinct geological structures can be identified: i) the upstream area, which is made up of tuffs, pozzolan and ignimbrite, and lava flows partially affected by current or recent floods; ii) the intermediate area, which consists mostly of clays and conglomerates, and a few outcropping strips of tuff, pozzolan and ignimbrite, a sign of an advanced erosive action compared to the previous section; iii) the downstream area, which is affected by current and recent floods with a typical alluvial valley conformation, with few sandy facies and almost no lava formations. The characteristic geological profile of this area includes various stratifications: from the bottom up it is possible to find clays and sandy clays covered by sands and conglomerates. Such geological layers form the basis for volcanic products, which are very inconsistent and therefore subject to intense erosive activity. The study area is indeed called 'Valle dei Calanchi', since these geological formations, called Badlands, are characteristic of this part of the region (i.e. in the municipality of Bagnoregio, and in the neighbouring Lubriano and Civitella d'Agliano).

Badlands are generated by the erosion of clays of the Pliocene deposited by marine waters around two million years ago due to atmospheric agents, in particular rain. The relative fluidity and inconsistency of this geological layer determine erosive phenomena which appear as deep cuts on the sides of the reliefs on which the vegetation can hardly develop and grow. These clay formations of the Badlands can be covered by layers of volcanic origin generated by the Vulsine apparatus.

The surface drainage network has deeply affected the valleys and the basin is still subject to rapid morpho-evolutionary dynamics, with erosion rates measured up to $10 \mathrm{~cm}$ per year. The annual average precipitation is $1000 \mathrm{~mm}$, while the maximum temperature is $13.8^{\circ} \mathrm{C}$ and the minimum is $1.2^{\circ} \mathrm{C}$. The territory of the river basin is not affected by hydraulic hazard, according the Tiber river basin Authority.

Thanks to this habitat and some uncommon bird species, the Rio Torbido river basin is classified as a Site of Community Importance (SIC) and a Special Protection Area (SPA) named 'Calanchi di Civita di Bagnoregio'.

\section{STEP 1 - Data Collection}

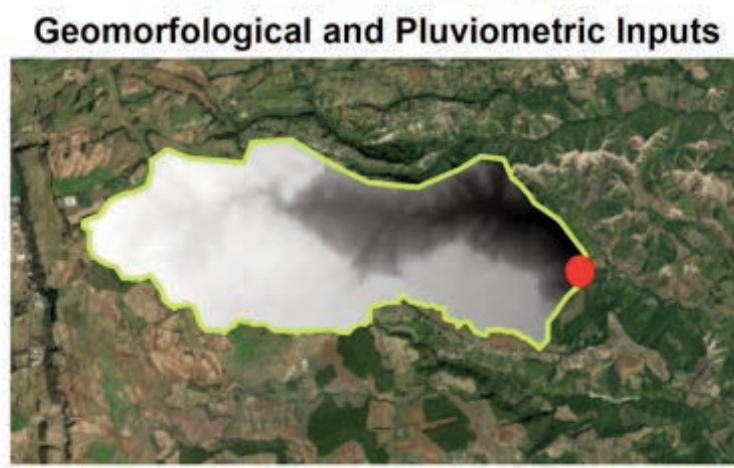

Rio Torbido sub-watershed

\section{STEP 3 - Hydraulic 2d Simulation (FLO-2d)}

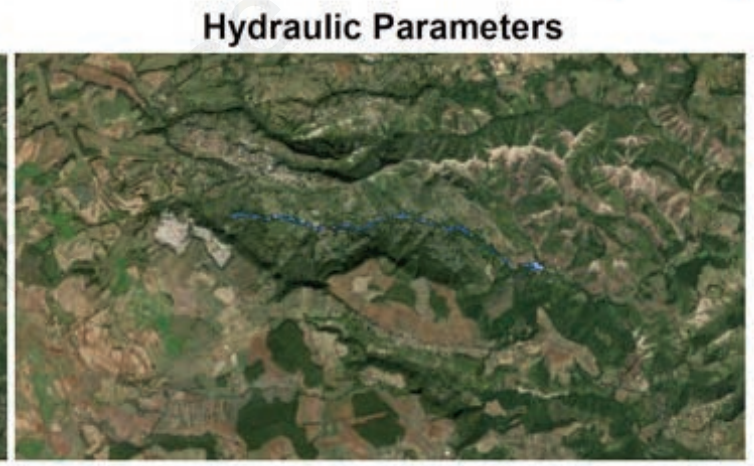

Flow Depth $T=1.5$ years $[\mathrm{m}]$
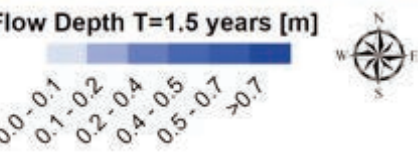

0.0 .0 .0 .0

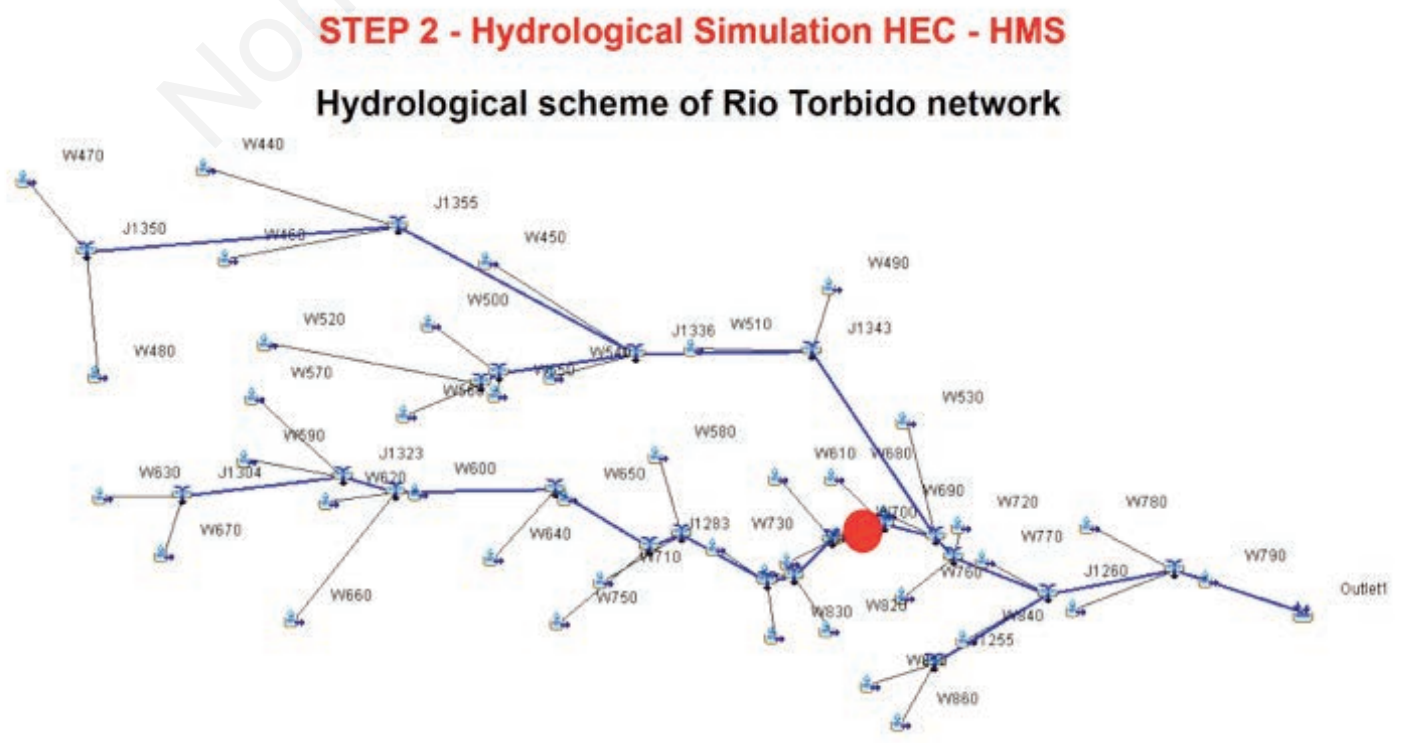

Figure 2. Scheme of hydrological and hydraulic modelling. 


\section{Hydrological modelling}

The hydrological analysis was carried out using the software HEC-HMS (Hydrologic Modelling System by the Hydrologic Engineering Centre of USACE - US Army Corps of Engineers). HEC-HMS simulates hydrological processes estimating the infiltration losses and the runoff volume, starting from a rainfall input. This software consists of the following fundamental databases: basin model, time series data and meteorological model.

The basin model component defines the physical characterization of the catchment area. The hydrological processes, such as infiltration, baseflow and runoff propagation, were sketched from a geomorphological point of view. The rainfall time series provided the input for the hydrological model. In this case study the rainfall timeseries is represented by a hyetograph for each considered return period. The rainfall analysis is performed using the meteorological model component, which can also estimate any potential evapotranspiration and snowpack melting. Finally, the hydrological simulation was carried out by combining the basin model, the meteorological model and the control specification, i.e. the time lag for which the simulation was carried out, as well as the calculation time discretization as shown in Figure 2. In particular, the input data used for the hydrological modelling of Rio Torbido are: i) digital elevation model (DEM) with a 10-meter resolution (Tarquini et al., 2007); ii) Corine land cover and look-up tables for assigning the curve number (Grimaldi et al., 2012); iii) VA.PI. rainfall data (Calenda et al., 1994). The first phase was conducted using a GIS tool, the HEC-GeoHMS extension. This tool enabled us to define the structure of the basin geomorphological model and to estimate the main parameters (e.g. geodetic coordinates, curve number in AMC II condition). The combination of the geomorphological model and the rainfall led to the definition of the hydrological model. The rainfall input was derived using the VA.PI. approach (Calenda et al., 1994) and transformed in runoff using the Mockus Instantaneous Unit Hydrograph (IUH) (1957). Table 1 lists the peak discharge values of the design hydrographs which were used as input for the hydraulic modelling.
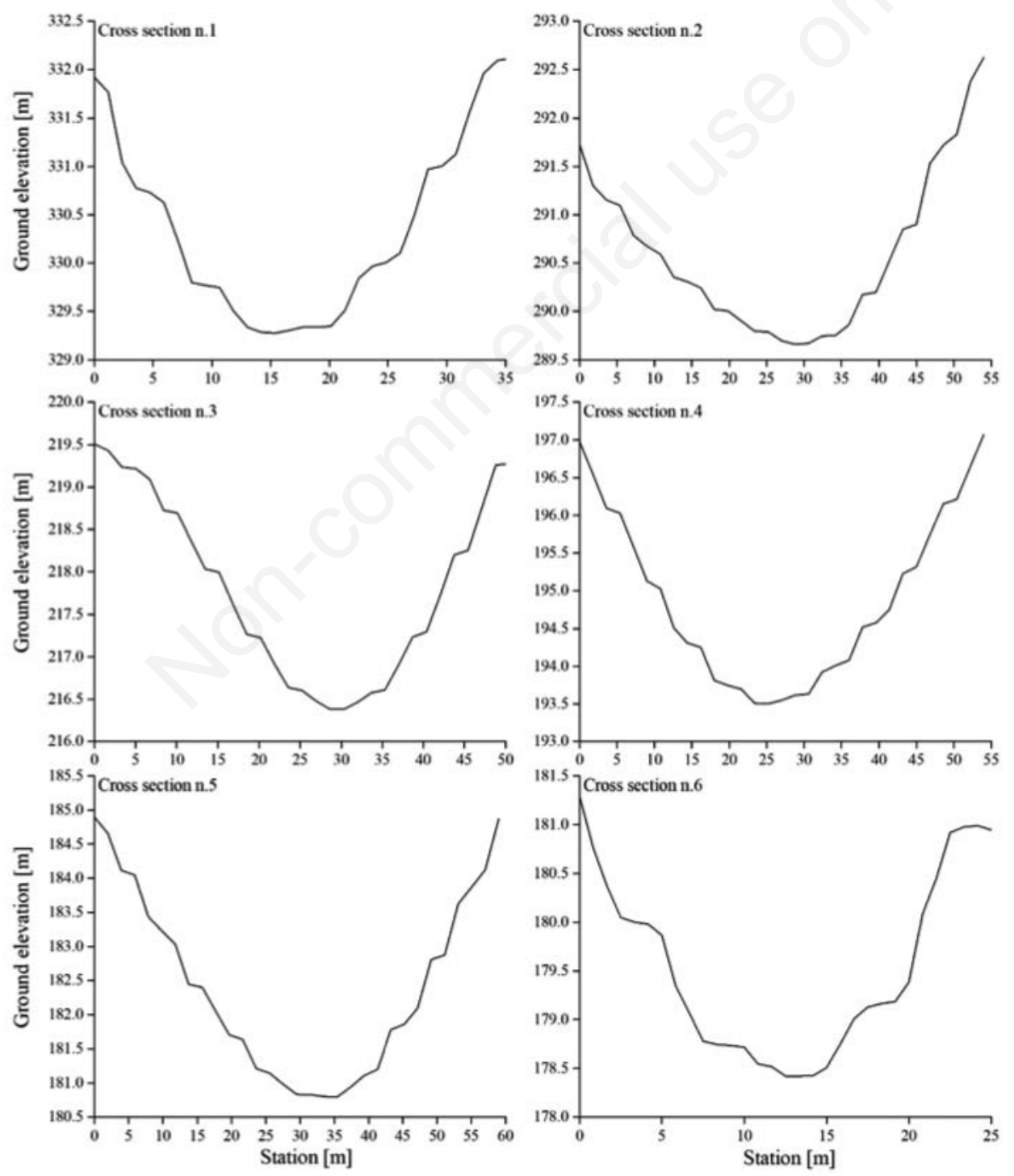

Figure 3. Observed cross section: topographic data. 


\section{Topographic data and hydraulic modelling}

It was necessary to map the flooding areas of the entire Rio Torbido main river in order to investigate the relationships between the modelled water flow depth and the riparian vegetation. As is well-known (Boreggio et al, 2018), the DEM is particularly important for flooding and debris flow studies.

For the construction of the geometric model elements, a highresolution DEM built through an unmanned aerial vehicle (UAV) was implemented as suggested by the literature for case-studies involving difficult access areas (Annis et al., 2020). The UAV flight was specifically designed and executed to support this research work. The UAV-based DEM (Drone-DEM hereinafter), made in 2020, had a resolution of $0.25 \mathrm{~m}$ and vertical accuracy of $\pm 0.10 \mathrm{~m}$

The Drone-DEM was generated adopting a quadcopter DJI Phantom 2 equipped with a GoPro Hero3+ model camera and a 2axis stabilization gimbal Zenmuse H3-2D model following a procedure which was fully described by Annis et al. (2020).

In order to evaluate flow depths and flow velocities for the established return period, the two-dimensional numerical model FLO-2D was applied (Peña and Nardi, 2018). Numerical simulations were carried out in a raster system, with a $5 \mathrm{~m}$ resolution, specified according FLO-2D user manual in order to avoid computational instabilities. In particular, the DEM adopted to simulate the flow on a floodplain topography was the result of Drone-DEM resampling. Figures 3 and 4 show the six control cross sections for post-processing analysis and their locations.

Regarding the estimation of roughness coefficients, it is well documented in the literature that riparian vegetation plays a crucial role in affecting the floodplain hydraulic roughness, which in turn significantly influences the dynamics of flood waves (Forzieri et al., 2011). Indeed, several studies were conducted to estimate the roughness coefficients of vegetated channels on a real scale for different management scenarios using, for example, an experimental campaign (Errico et al., 2018) or remote sensing data (Forzieri et al., 2012). However, considering that in the assumed return periods only the river, and not the floodplain, has been interested by the flood depth and on the basis of the survey data analyses of all documented cross sections, a Manning uniform coefficient equal to $0.04 \mathrm{~s} / \mathrm{m}^{1 / 3}$ was adopted as roughness parameter for hydraulic modelling. The simulation of the flooding was obtained through the numerical integration of the conservation equation of fluid volume and the motion equation (full dynamic wave momentum equation). The model computational time for the four scenarios was as follows: 7.6 hours for a 1.5 -year return period (scenario 1); 10.1 hours for a 2 year-return period (scenario 2); 12.6 hours for a 2.5-year return period (scenario 3); 14 hours for a 30 year-return

Table 1. Peak flow (Q) for the considered return periods (T).

\begin{tabular}{lc} 
T [years] & $0\left[\mathrm{~m}^{3} / \mathrm{s}\right]$ \\
1.5 & 20 \\
2 & 27 \\
\hline 2.5 & 32 \\
30 & 143 \\
\hline
\end{tabular}
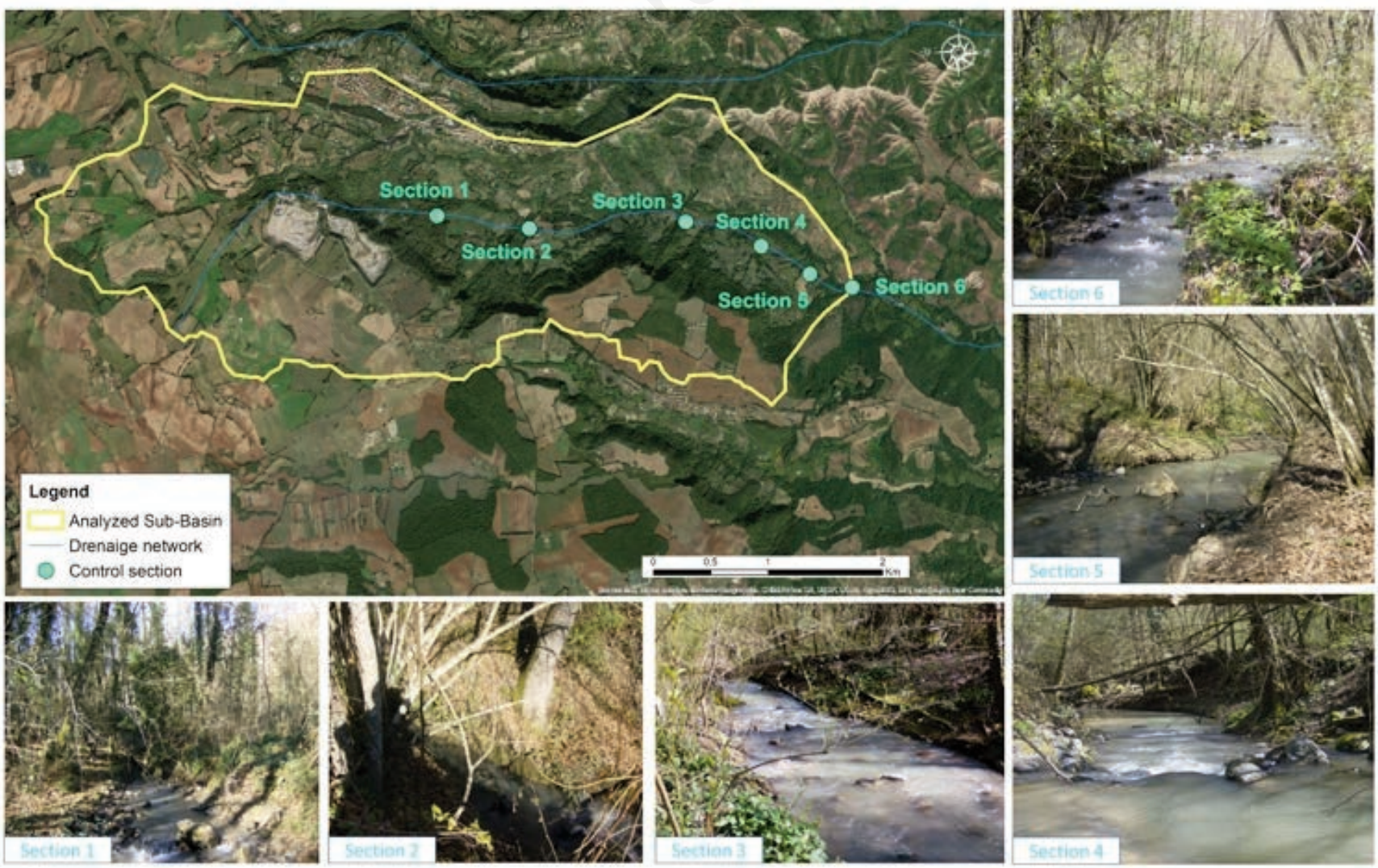

Figure 4. Location of the six control sections. 
period (scenario 4). The first three scenarios were derived from the scientific literature, while the scenario related to the 30 -year return period was simulated in accordance with the Italian legislation regarding water course maintenance.

\section{Riparian species detected in the study area}

The most characteristic species of riparian formations that were detected in the study area were Salix alba, Populus nigra, Populus alba and Alnus glutinosa. For the study area, the vegetational survey was conducted in the six control sections (see Figure 4). All species belonging to the Salicaceae family were widely present and developed, both in terms of diametrical dimensions and of longitudinal development. Only $P$. nigra showed smaller dimensions. Other identified species were A. glutinosa, Quercus robur, located on the hydrographic left of the river, plus Quercus cerris and Robinia pseudacacia. The only shrub present along the riverbed was Sambucus nigra, with polycormic individuals and maximum heights of $3 \mathrm{~m}$. The list of the classified species is reported in Table 2.

\section{Results and discussion}

The results of FLO-2D were analysed for all the assumed scenarios. To analyse the effects of the hydraulic simulations, the

Table 2. Riparian species recorded (" $x$ " indicates detected species in each cross section).

\begin{tabular}{|c|c|c|c|c|c|c|}
\hline Riparian species & Section 1 & Section 2 & Section 3 & Section 4 & Section 5 & Section 6 \\
\hline Acer campestre & $\mathrm{x}$ & & & & & $\mathrm{x}$ \\
\hline Alnus glutinosa & & & & & 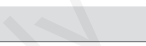 & $\mathrm{x}$ \\
\hline Crataegus monogyna & $\mathrm{x}$ & $\mathrm{x}$ & & & $\mathrm{x}$ & $\mathrm{x}$ \\
\hline Populus alba & $\mathrm{x}$ & $\mathrm{x}$ & & & + & \\
\hline Populus nigra & & $\mathrm{x}$ & $\mathrm{x}$ & $\mathrm{x}$ & $\mathrm{x}$ & \\
\hline Prunus spinosa & & & & & & $\mathrm{x}$ \\
\hline Quercus robur & $\mathrm{x}$ & & & C & & \\
\hline Quercus cerris & & $\mathrm{x}$ & & s & $\mathrm{x}$ & \\
\hline Robinia pseudacacia & & $\mathrm{x}$ & $\mathrm{x}$ & $\mathrm{x}$ & $\mathrm{x}$ & $\mathrm{x}$ \\
\hline Salix alba & $\mathrm{x}$ & $\mathrm{x}$ & $\mathrm{x}$ & $\mathrm{x}$ & & $\mathrm{x}$ \\
\hline Sambucus nigra & $\mathrm{x}$ & $\mathrm{x}$ & $\mathrm{x}$ & $\mathrm{x}$ & $\mathrm{x}$ & $\mathrm{x}$ \\
\hline
\end{tabular}

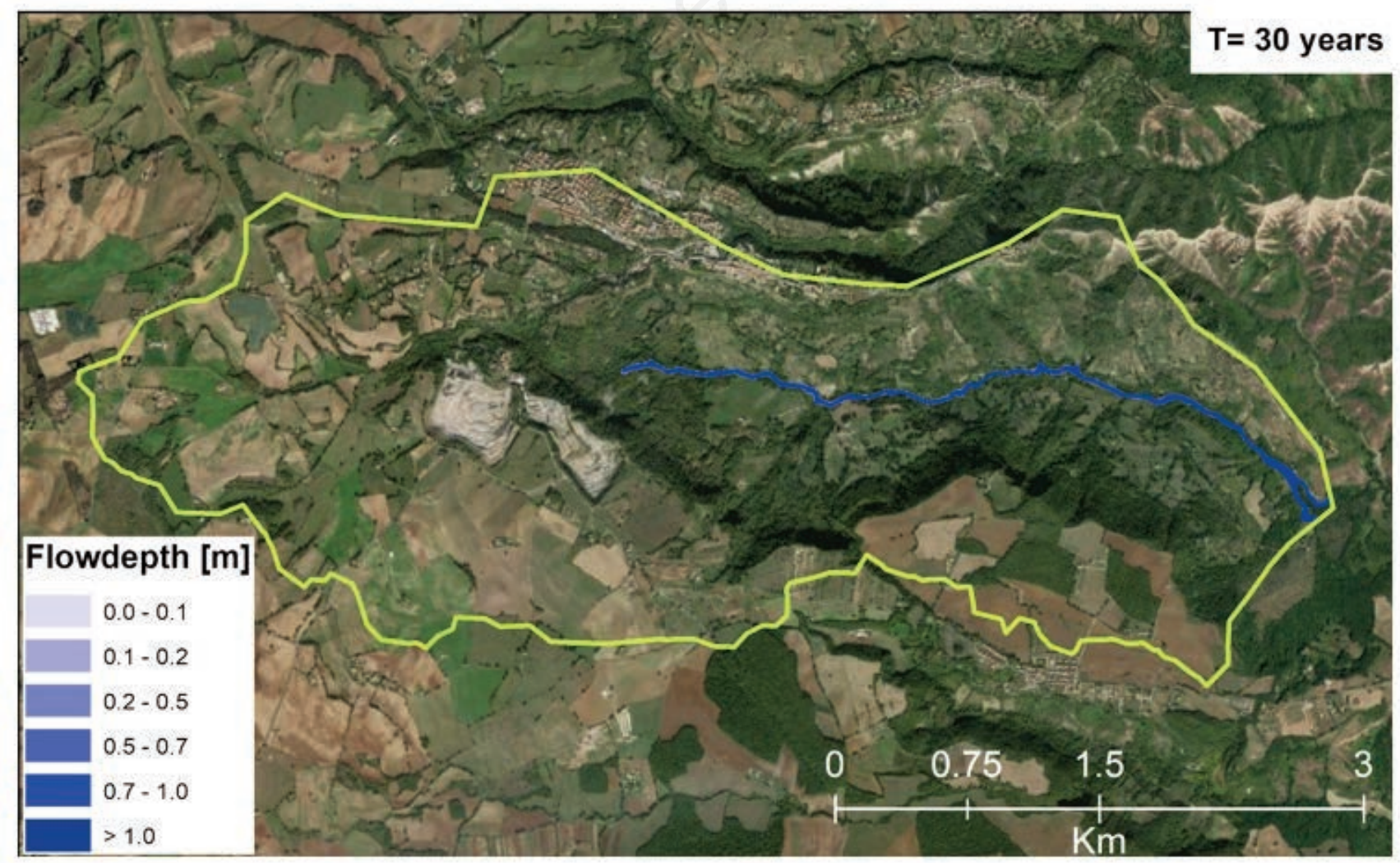

Figure 5. Flooding areas for scenario number $4(T=30$ years). The watershed analysed is in green. 
results were filtered excluding the marginal flooding areas (Pellicani et al., 2018), i.e. areas with negligible flow depths and flow velocity values. The Tiber River Basin Authority guidelines were followed to define the marginal area limits. The equation used to define marginal areas is as follows:

$h^{*}=-0.384 v+0.5$

where $h^{*}(\mathrm{~m})$ represents the maximum acceptable 'flow-depth' value to neglect flooding effects and $v(\mathrm{~m} / \mathrm{s})$ is the maximum 'flow velocity' value in the specific cell. In this way, each cell with a value of 'flow-depth' $h$ lower than the corresponding limit value of $h^{*}$ was considered in a hydraulic safety condition (in other terms 'not a flooding area').

A comparative analysis between the different scenarios was also carried out. In particular, flooding areas and flow depths for $T$ $=30$ years are shown in Figure 5. Summary of flooding areas for
Table 3. Summary of flooding area comparison.

\begin{tabular}{lcccc} 
Flooding area $\left[\mathrm{km}^{2}\right]$ & \multicolumn{5}{c}{ Return period T [years] } \\
& 1.5 & 2 & 2.5 & 30 \\
Not filtered & 0.14 & 0.15 & 0.15 & 0.21 \\
Filtered & 0.11 & 0.12 & 0.12 & 0.19 \\
\hline
\end{tabular}

the considered return periods are reported in Table 3.

Figure 6 shows the maximum flow depth and the ratio $(b / h)$ between the floodplain width (b) and the flow depth (h) for the six investigated cross sections. The $\mathrm{b} / \mathrm{h}$ ratio was always greater than 10 , therefore the riparian vegetation influence in terms of roughness can be considered negligible (Masterman and Thorne, 1975), justifying the use of a constant value for the entire river bed.

Despite having an almost constant flooding area in the first three scenarios (see Table 3), Figure 6 shows the variability of the

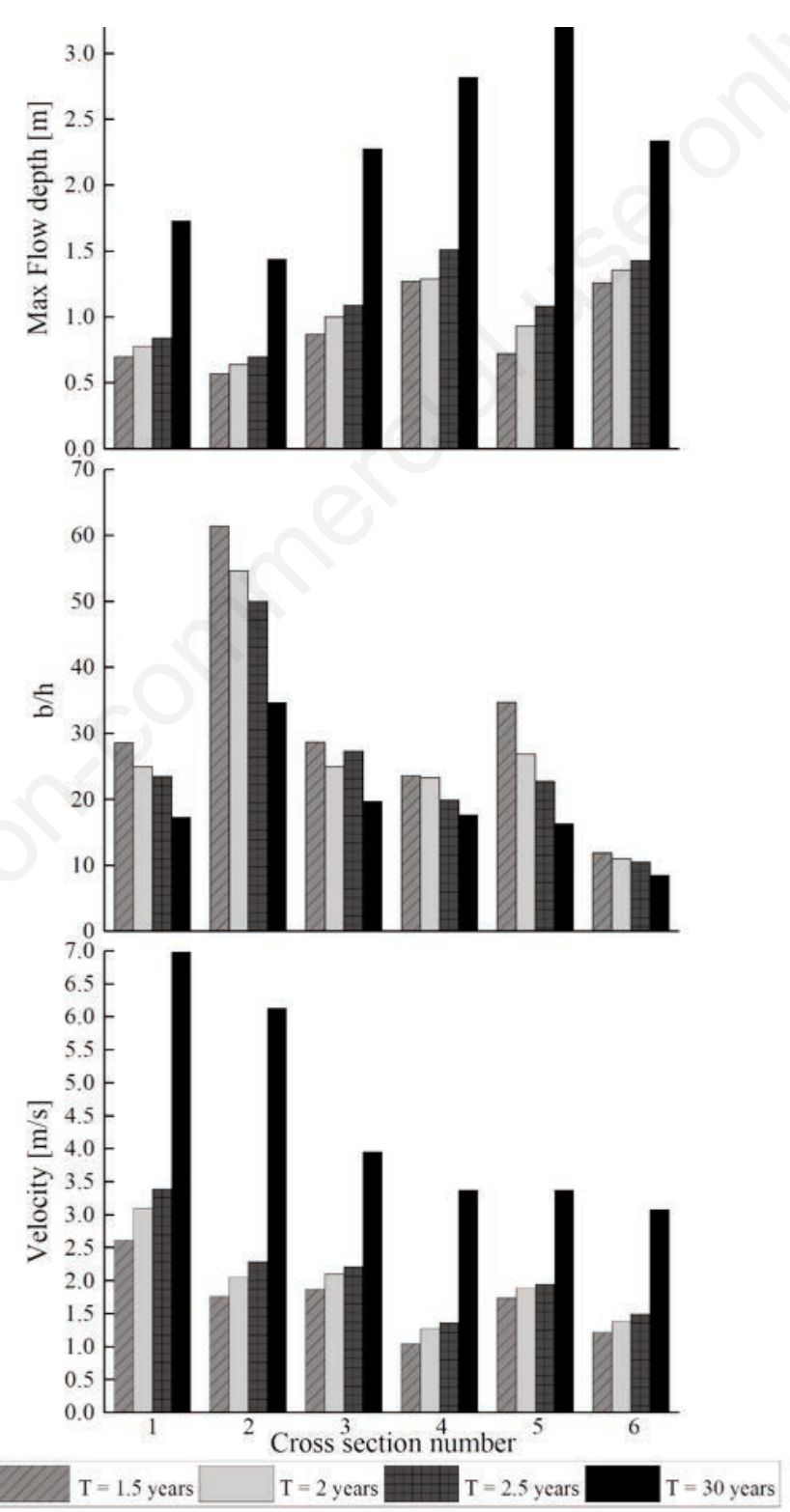

Figure 6. Max flow depth, b/h ratio and average flow velocity in the six cross sections under investigation. 


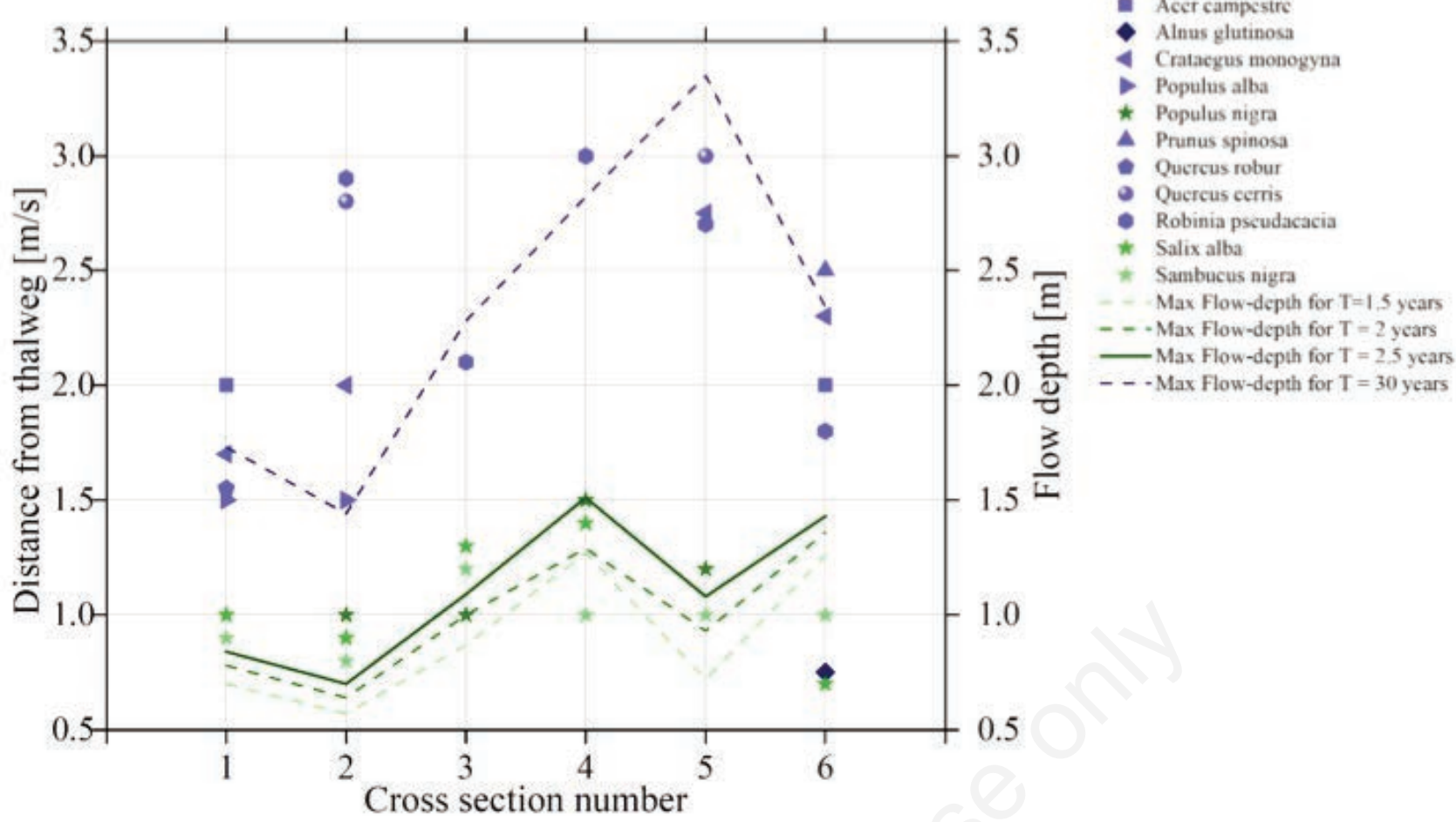

Figure 7. Max flow depth in the six control sections and riparian species position.

hydrodynamic characteristics $(h, v)$ along the considered river reach. This tendency can be justified by the topographic and geometric variability of the Rio Torbido cross sections, as shown in Figure 3. During the field survey, a strong heterogeneity of the vegetation species was also found (see Figure 4).

Figure 7 shows the water levels obtained from the hydraulic modelling carried out for the analysed return periods and the position with respect to thalweg of the woody species detected in the six control sections. The graph shows that the tree species can be split into three classes.

The first class is called 'non riparian species', i.e. the tree species that were always outside of the flooding area, for each considered return period. This group includes: Acer campestre, Crataegus monogyna, P. alba, Prunus spinosa, Q. robur, Q. cerris and $R$. pseudacacia.

In Figure 7 this group is depicted with light blue symbols.

The second class is called submerged species, i.e. the tree species that are located under the water level. The group of trees closer to the riverbed remains almost unchanged, as it consists of A. glutinosa and S. nigra. Although only one individual of A. glutinosa (indicated in Figure 7 with a dark blue rhombus) was identified in the various sections of the investigated portion of the river, several specimens were downstream and in the intermediate section, as shown in Figure 4.

The third class is classified as 'riparian species', i.e. the tree species that are positioned in proximity of flooding area boundary. This group included $S$. alba, P. nigra and in some cases even $S$. nigra, marked the limit of the riparian area. In Figure 7 this group is represented with green stars.

Our results are in agreement with previous studies on similar areas (Bertoldi et al., 2011a, 2011b), showing the remarkable influ- ence of vegetation in defining riparian areas. It should also be noted that the woody species of the third class were in line with the areas defined by the 2.5-year return period, which could therefore be considered the most useful to define the Rio Torbido bankfull discharge.

\section{Conclusions}

This work combines topographic observations and vegetation surveys with hydrological-hydraulic analysis in the Rio Torbido River, in central Italy, in order to confirm a possible correlation between the colonization of the riverbank by woody riparian species and the bankfull discharge.

Using a standard hydrological approach, four design hydrographs related to the assumed return periods were estimated. Afterwards, the flooding areas were identified by applying a twodimensional hydraulic modelling.

Results are in agreement with previous studies (Gurnell, 1995; Petts and Gurnell, 2005) in similar areas and confirm that is possible to correlate the presence of riparian vegetation to the bankfull discharge. In particular, woody riparian species are located along a significant portion of Rio Torbido river, where several specimens of S. alba, P. alba, P. nigra, A. glutinosa, C. monogyna, P. spinosa, $S$. nigra, $Q$. robur, $Q$. cerris and $R$. pseudacacia were surveyed.

However, the tree species closer to the bankfull are $P$. nigra, $S$. alba, S. nigra and A. glutinosa in the downstream part of study area, where clays are dominant.

The described approach can provide an easy-to-use tool for supporting decision-makers in the preliminary identification of riparian areas, without implementing complex numerical mod- 
elling. However, further improvements of this research are needed and are in progress in order to increase the correlation accuracy between the hydraulic characteristics of floodplain areas and the presence of riparian species. Future research will indeed focus on the submersion duration of the investigated species and the use of UAV for classifying the riparian vegetation. This will also enable us to investigate in greater depth the influence on roughness parameter by vegetation height and diameter.

\section{References}

Annis A., Nardi F., Petroselli A., Apollonio C., Arcangeletti E., Tauro F., Belli C., Bianconi R., Grimaldi S. 2020. UAV-DEMs for small-scale flood hazard mapping. Water 12:1717.

Arcement G.J., Schneider V. 1989. Guide for selecting Manning's roughness coefficients for natural channels and flood plains. US Geological Survey Water Supply Paper 2339.

Bendix J., Hupp C.R. 2000. Hydrological and geomorphological impacts on riparian plant communities. Hydrol. Process. 14:2977-90.

Bertoldi W., Drake N.A., Gurnell A.M. 2011a. Interactions between river flows and colonizing vegetation on a braided river: exploring spatial and temporal dynamics in riparian vegetation cover using satellite data. Earth Surf. Process. Land. 36:1474-86.

Bertoldi W., Gurnell A.M., Drake N.A. 2011b. The topographic signature of vegetation development along a braided river: results of a combined analysis of airborne lidar, color air photographs and ground measurements. Water Resour. Res. 47:W06525.

Biedenharn D.S., Copeland R.R, Thorne C.R., Soar P., Hey D.R. 2000. Effective discharge calculation. US Army Corps of Engineers.

Boreggio, M., Bernard, M. Gregoretti C. 2018. Evaluating the influence of gridding techniques for Digital Elevation Models generation on the debris flow routing modelling: a case study from Rovina di Cancia basin (North-eastern Italian Alps). Front. Earth Sci. 6:89.

Calenda G., Campolo F., Cosentino C., Guercio R. (a cura di). 1994. Valutazione delle piene nei bacini delle sezioni idrografiche di Roma e Pescara. In La valutazione delle piene in Italia-Rapporto Nazionale di Sintesi, Bozza, CNR-GNDCI, Allegato F. Available from: http://www.idrologia.polito. it/gndci/rapporti/RmPe.htm.

Copeland R.R., Biedenharn D.S., Fischenich J.C. 2000. Channelforming discharge. US Army Corps of Engineers.

D.P.R. 14 April 1993. Atto di indirizzo e coordinamento alle regioni recante criteri e modalità per la redazione dei programmi di manutenzione idraulica e forestale. Available from: https://www.gazzettaufficiale.it/eli/id/1993/04/20/093A2321/s $\mathrm{g}$

Džubáková K., Molnar P., Schindler K., Trizna M. 2015. Monitoring of riparian vegetation response to flood disturbances using terrestrial photography. Hydrol. Earth Syst. Sci. 19:195-208.

Errico A., Pasquino V., Maxwald M., Chirico G.B., Solari L., Preti
F. 2018. The effect of flexible vegetation on flow in drainage channels: Estimation of roughness coefficients at the real scale. Ecol. Engine. 120:411-21.

Forzieri G., Castelli F., Preti F. 2012. Advances in remote sensing of hydraulic roughness. Int. J. Remote Sens. 33:630-54.

Forzieri G., Degetto M., Righetti M., Castelli F., Preti F. 2011. Satellite multispectral data for improved floodplain roughness modelling. J. Hydrol. 407:41-57.

Grimaldi S., Petroselli A., Nardi F. 2012. A parsimonious geomorphological unit hydrograph for rainfall-runoff modelling in small ungauged basins. Hydrol. Sci. J. 57:73-83.

Gurnell A.M. 1995. Vegetation along river corridors: hydrogeomorphological interactions changing River Channels. John Wiley and Sons, Chichester, UK, pp. 237-260.

Gurnell A. 2014. Plants as river system engineers. Earth Surf. Process. Landf. 39:4-25.

Hughes F.M.R. 1997. Floodplain biogeomorphology. Progr. Phys. Geogr. Earth Environ. 21:501-29.

Knighton A.D. 1984. Fluvial forms and processes. Arnold, London, UK.

Louckova B. 2011. Vegetation-landform assemblages along selected rivers in the Czech Republic, a decade after a 500 - year flood event. River Res. Appl. 28:1275-88.

Masterman R., Thorne C.R. 1975. Predicting influence of bank vegetation on channel capacity. J. Hydr. Div. ASCE 101:87184.

Merritt D.M., Scott M.L., Poff N.L., Auble G.T., Lytle D.A. 2010. Theory, methods and tools for determinating environmental flows for riparian vegetation: riparian vegetation-flow response guilds. Freshwater Biol. 55:206-25.

Mockus, V. 1957. Use of storm and watershed characteristics in synthetic hydrograph analysis and application. American Geophysical Union, Pacific Southwest Region, Sacramento, CA, USA.

Navratil O., Albert M.B., Herouin E., Gresillon J $\square$ M. 2006. Determination of bankfull discharge magnitude and frequency: comparison of methods on 16 gravel-bed river reaches. Earth Surf. Process. Landf. 31:1345-63.

Petts G.E., Gurnell A.M. 2005. Dams and geomorphology: research progress and future directions. Geomorphol. 71:2747.

Pellicani R., Parisi A., Iemmolo G., Apollonio C. 2018. Economic risk evaluation in urban flooding and instability-prone areas: the case study of San Giovanni Rotondo (Southern Italy). Geosciences 8:112.

Peña F., Nardi F. 2018. Floodplain terrain analysis for coarse resolution 2D flood modeling. Hydrology 5:52.

Tabacchi E., Lambs L., Guilloy H., Planty-Tabacchi A.M., Muller E., Decamps H. 2000. Impacts of riparian vegetation on hydrological processes. Hydrol. Process. 14:2959-76.

Tarquini S., Isola I., Favalli M., Battistini A. 2007. TINITALY, a digital elevation model of Italy with a $10 \mathrm{~m}$-cell size (Version 1.0) [Data set]. Istituto Nazionale di Geofisica e Vulcanologia (INGV).

Williams G.P. 1978. Bank-full discharge of rivers. Water Resour. Res. 14:1141-54.

Woodyer K.D. 1968. Bankfull frequency in rivers. J. Hydrol. 6:114-42. 